\title{
Seasonal Infection of the Weed Dyer's Woad by a Puccinia sp. Rust Used for Biocontrol, and Effects of Temperature on Basidiospore Production
}

\author{
Karen M. Flint and Sherman V. Thomson, Department of Biology, Utah State University, Logan 84322-5305
}

\begin{abstract}
Flint, K. M., and Thomson, S. V. 2000. Seasonal infection of the weed dyer's woad by a Puccinia sp. rust used for biocontrol, and effects of temperature on basidiospore production. Plant Dis. 84:753-759.

Potted dyer's woad rosettes exposed to natural rust inoculum at field sites became infected when exposed from late April through early July, depending upon the location. The latent period between exposure and symptom expression varied from 9 to 54 weeks. The length of this latent period was unrelated to either the age of plants at exposure or the exposure period itself. The age of rosettes at the time of exposure did not affect the incidence of infection. Fall infection of potted rosettes occurred, but the incidence was low. When naturalized stands of woad were inoculated with teliosori, either fresh or dried, the incidence of infection was 58 to $76 \%$, compared with 2 to $7 \%$ incidence in noninoculated plants. Basidiospores were readily produced from intact teliosori when suspended over water agar, with the highest rate of production between 3 and $6 \mathrm{~h}$ of incubation, at 10 to $20^{\circ} \mathrm{C}$. The optimum temperature for basidiospore production over a 24 -h period was $15^{\circ} \mathrm{C}$, but they were produced at temperatures as low as $5^{\circ} \mathrm{C}$, although not at $25^{\circ} \mathrm{C}$. These lower-than-expected temperatures for spore production corroborate the field evidence that dyer's woad rust most actively infects in springtime, when temperatures are comparatively low and rainfall is more frequent.
\end{abstract}

Additional keywords: biological control, mycoherbicide, noxious weed, Puccinia consimilis, $P$. thlaspeos

Dyer's woad (Isatis tinctoria L., Brassicaceae) is a plant well known in antiquity as a source of blue dye, the predecessor of indigo, and valued so highly that some European economies were built around its cultivation, processing, and trade. Woad was cultivated for dye in colonial America and escaped to become a naturalized inhabitant of meadows and disturbed areas. Now uncommon in the native floras of Europe, Britain, and the eastern United States, woad began to disappear when its cultivation as a dye crop diminished with the advent of indigo. Recently, however, dyer's woad has achieved a new and less benign notoriety. With its introduction into the arid West, it has proliferated extensively and is now listed as a noxious weed in eight western states (S. A. Dewey, personal communication). In 1985, woad was spreading at a rate of $14 \%$ per year on Bureau of Land Management rangeland in the Pacific Northwest (19). It had increased more than 35-fold from 1969 to

Corresponding author: Sherman V. Thomson E-mail: shermt@ext.usu.edu

* The $\boldsymbol{e}$-Xtra logo stands for "electronic extra" and indicates the article available on-line contains color not included in the print edition.

Accepted for publication 17 March 2000.

Publication no. D-2000-0427-02R

(c) 2000 The American Phytopathological Society
1985 (12) on national forest land in the Intermountain region.

The natural history of dyer's woad, and its history and impact in the Intermountain West, have been previously documented is a winter annual, biennial, or short-lived perennial $(9,24)$, whose seeds germinate in the spring or fall and overwinter as rosettes. After vernalization (2), the rosettes bolt to form a stalk that may produce 300 to 500 or more seeds (9). The plants are drought-hardy and very competitive with native rangeland vegetation (23). Root sprouting is a common phenomenon and accounts for the regeneration of plants that have been cut or grazed (4). However, reproduction and spread of woad is mainly by seed; thus, control measures that target seed production will be most successful (9).

Callihan (3) and Evans (8) describe the various woad control strategies commonly used, including hand-pulling or cultivation, cultural strategies such as reseeding with competitive plants, and herbicide application. In noncultivated rangeland or forest, biological control may be the only practical means of suppressing large infestations of dyer's woad.

A rust on dyer's woad was first observed in 1979 in Cheatbeck Canyon, Caribou County, Idaho (B. Blanchette, personal communication), and was tentatively identified as Puccinia thlaspeos (J. F. Hennen, personal communication). However, Kropp et al. (15) have recently shown by (4,7-9,13,20,22,23). Briefly, dyer's woad
DNA sequence analysis that the rust is closely related to, or conspecific with, Puccinia consimilis. The identity of the fungus is not entirely resolved. The rust on dyer's woad is microcyclic, with no aecia or uredia, whereas $P$. consimilis is demicyclic with aecia (1). On woad leaves, bright yellow, type-4 spermagonia (11) appear first but are soon intermingled with cinnamon-colored teliosori. Both structures are more prevalent on the abaxial leaf surface and are often clustered at the distal end; but the entire underside of the leaf is commonly crowded with sori and spermagonia. Spermagonia are often apparent on the adaxial leaf surfaces without teliosori. Infected woad rosettes often have normallooking older leaves on the periphery, but the younger, center leaves are usually chlorotic due to the development of spermagonia. Infected rosette and cauline leaves are variably chlorotic, brittle, and twisted about the midvein, with leaf margins profoundly rolled toward the abaxial surface. As the plant bolts, it is often stunted, thickened, and brittle. Affected plants are typically chlorotic before spermagonia and sori develop; but the sporebearing structures eventually arise even in the apical leaf clusters (Fig. 1). Flowers, which are uncommon on infected plants, also bear sori and rarely produce seeds (17). Plants may be partially infected, with one or more symptomatic stalks amid healthy-appearing stalks. Root infection allows the fungus to survive in plants when aboveground portions are removed by grazing, fire, cultivation, or other disturbances (14).

Sori of the woad rust become ash-gray or "cinereous" when the teliospores germinate to produce promycelia and basidiospores. Basidiospores are obovate and measure 9 (7 to 12$) \times 7.5$ (6 to 10$) \mu \mathrm{m}$. As the teliosori age, they become darker and recede into the leaf, eventually leaving a mere dark spot. This process coincides with leaf senescence; older leaves near the base of the plant senesce while younger leaves are still succulent, with productive teliosori.

Between 1980 and 1988, the incidence of disease at the original Cheatbeck Canyon site increased from less than $1 \%$ of plants infected to greater than $80 \%$ (16); but the observed range of the rust was still limited to a few patches of woad (less than 0.5 ha total) near Cheatbeck Canyon and in northern Utah (S. V. Thomson, unpublished). In 1988, Dewey et al. (7) mapped 1,741 points of dyer's woad infestation on 
over 149,000 ha in the Cache National Forest in northern Utah and found no rust infection (S. A. Dewey, personal communication). However, by the early 1990s, outbreaks of rust were relatively common in Utah, and by 1997, rust was so widespread in northern Utah that it was difficult to find dyer's woad populations that were not infested.

While woad rust effectively colonizes dyer's woad populations without human intervention, biological control of the weed infection through inoculation. Early attempts by Lovic (16) to infect woad met with limited success. Although Lovic's work indicated that transmission of rust was possible, an incomplete understanding of the life history of the fungus may have hampered early efforts. Accordingly, we studied aspects of the disease cycle and epidemiology of rust on dyer's woad, including the timing of natural infections, symptom expression, and the temperature range at which basidiospores are produced. Our immediate objective was to determine the infection period of the rust and the optimum conditions for production of might be enhanced by augmentation of

basidiospores. Our long-range goal was to determine how to manage the rust to optimize it as a biocontrol of dyer's woad.

\section{MATERIALS AND METHODS}

Timing of field infections. Woad seed was collected in 1990 and 1991 from apparently healthy plants, threshed, stored at $5^{\circ} \mathrm{C}$ in an airtight container, and used for experiments the following season. Plants were grown from seed in 10.2-cm (4-in) fiber pots in a commercial potting medium containing slow-release fertilizer in 1991, and in a steam-pasteurized soil mix (2:1 peat:Kidman sandy loam) in 1992. Plants were grown in a greenhouse or, when weather permitted, outdoors at a site isolated from sources of woad rust.

Planting of woad seed for these experiments was staggered to provide plants of varying ages for each exposure period. Ten to 60 pots, plus extras for replacements, were seeded per planting date. Plants to be exposed to rust in 1991 were seeded on 22 March, at 2-week intervals from 12 April to $19 \mathrm{July}$, and 15 August. The number of woad plants per pot varied from one to four. In 1992, seeds were planted at 2-week

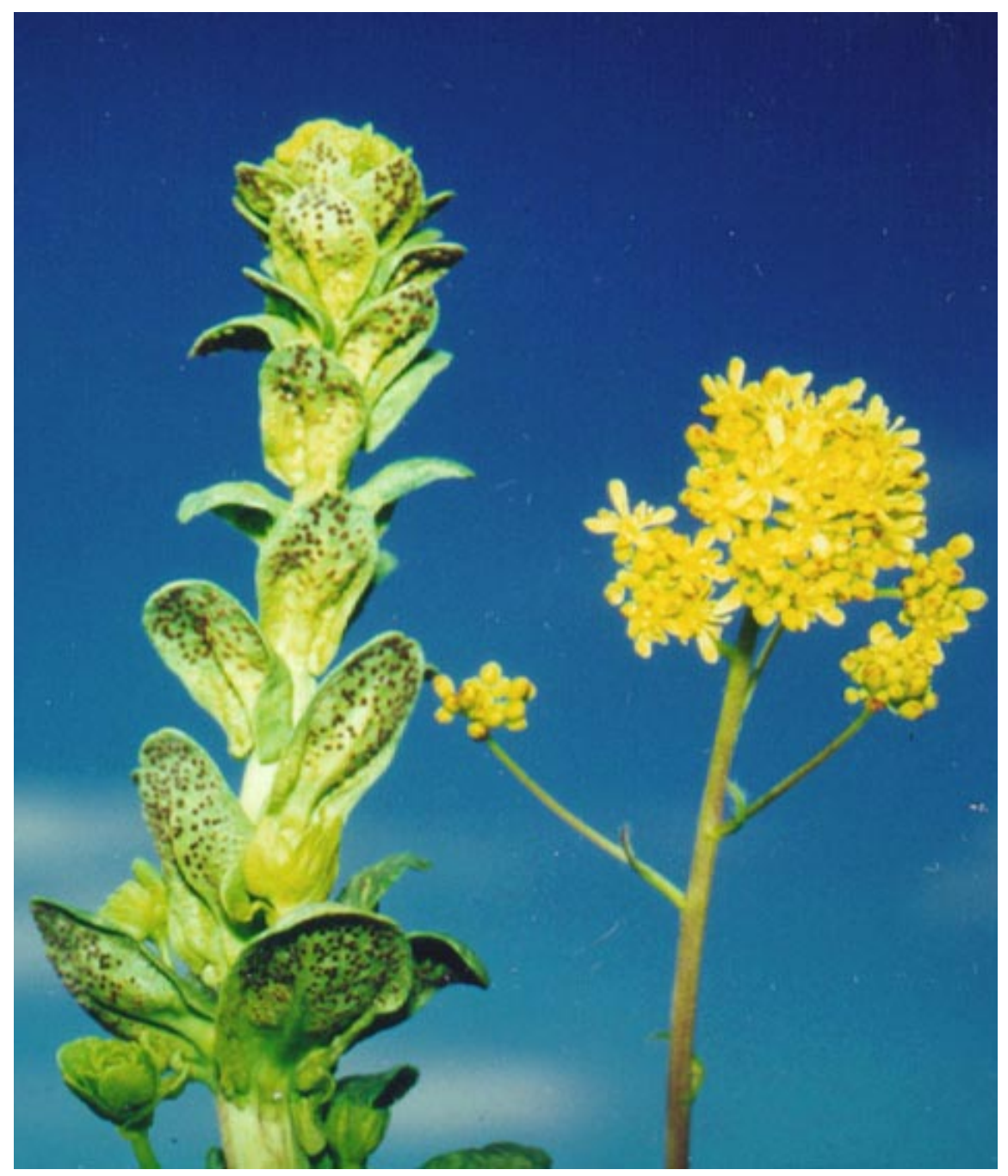

Fig. 1. Healthy dyer's woad flowers (right) and rust-infected stem (left) with teliosori on the infected leaves. Flowers are rarely produced on rust-infected stems. intervals from 14 January through 17 July. Several seeds were planted in each pot, but seedlings were thinned to two plants per pot before pots were transferred to the experimental sites. In both years, experimental units were individual pots.

In 1991, two exposure sites were selected. One was a rocky, sagebrush-covered, south-facing hillside $(1,350-\mathrm{m}$ elevation) adjacent to US 89-91 at the mouth of Box Elder Creek canyon east of Brigham City (BC), UT. The other site was a small disturbed clearing (1,800-m elevation) in a grove of bigtooth maple (Acer grandidentatum) in Wellsville Canyon (WC), UT. The WC site was shaded part of the day. In 1992, WC was used again, as well as a sunny site at the Green Canyon (GC) Ecology Research Station (1,460-m elevation) in North Logan, Cache County, UT. At BC and $\mathrm{WC}$, the naturalized dyer's woad population contained many symptomatic rust-infected plants, which produced inoculum for the experiment. Since there were no rust-infected plants growing at GC, infected rosettes were transplanted in a raised bed in fall 1991 to provide inoculum.

Plants were exposed to rust inoculum in groups consisting of a varied number of pots per age group, placed at the same site during the same approximately 2-week period. Plants were hand-watered as needed.

In 1991, plants were approximately 2, 4, $6,8,10$, or 12 weeks old at the beginning of each exposure period. There were at least two and up to six ages represented at each exposure period. The number of pots of each age group varied between exposure periods but was usually five pots at $\mathrm{BC}$ and 10 at WC. The first groups of plants were placed at WC and BC on 12 April and 26 April, respectively. Plants were exposed through 19 July at BC and through 16 August at WC. After these dates, inoculum was apparently no longer available because resident infected plants had died. Nevertheless, 20 4-week-old plants were exposed at the BC and WC sites between 16 September and 28 October 1991 as a test for fall infection.

At WC in 1992, generally 10 pots each of plants aged 2, 8, and 14 weeks were exposed at approximately 2-week intervals from 23 April through 23 September. At GC, usually 10 plants per age group were exposed at 2-week intervals from 23 April through 13 August.

Experiments specifically assaying for fall infection were conducted at three sites in 1992, as follows. At WC, 10 pots each of 2-, 10-, and 14-week-old plants were exposed 23 September through 9 October. At GC, 10 each of 8- and 14-week-old plants were placed 10 September to 2 November. From mid-September to 2 November, 5 to 20 plants each of ages 3,8 , and 14 weeks were placed at a site in North Logan (NL), UT, alongside potted, bolted, 
and rust-infected dyer's woad bearing teliosori.

At the end of each exposure period in both 1991 and 1992, the groups of potted woad plants were transferred to a site near Logan (LO) that was isolated from known sources of woad rust. Plants were observed for symptoms of rust through November after the plants were exposed, and commencing again the following March. Observations were curtailed during the winter months, as plants were generally dormant and were often covered with snow. Pots containing symptomatic plants were immediately removed to exclude inoculum sources from the LO site. Plants that had never been exposed to rust inoculum were maintained at LO as checks. Plants were kept at LO either until they showed symptoms or until the summer following their exposure, at which time they had usually bolted and were considered to be uninfected.

Temperature, leaf wetness, and rainfall were monitored at WC in 1992 using an Easylogger (Model EL824-GP, Omnidata, Logan, UT) and a tipping bucket rain gauge. Temperature and leaf wetness were monitored at GC using a Datapod (Model DP223, Omnidata).

With the exceptions noted below, 1991 and 1992 infection data (infected versus not infected) were analyzed using the chisquare test for binomial response data (6). Main effects (exposure date and age) and interactions were tested against the null hypothesis that neither main effects nor interactions affected percent infection. Data for periods each year in which no infections occurred were not included in the analysis. Fall infection data were not analyzed, as there were so few infections. Likewise, the interaction of age and exposure date for data from $\mathrm{BC}$ and $\mathrm{WC}$ in 1991 were not tested because the designs were not balanced.

Inoculation of natural woad stands. On 28 May 1993, symptomatic dyer's woad plants without roots were collected at various sites in Cache and Box Elder Counties. Dry inoculum was prepared by air- and oven-drying the plants for 4 days at 25 to $35^{\circ} \mathrm{C}$. Leaves were stripped from the stems and crumbled between finely corrugated rubber mats mounted on a wooden block and tray. The dry inoculum was then sifted through an 18-mesh screen to remove larger debris. Talc was added as an extender in a 1:3 talc:inoculum ratio.

Liquid inoculum suspensions were prepared 3 and 4 June from plants that had been collected 1 June and stored at $5^{\circ} \mathrm{C}$. For each suspension, $250 \mathrm{~g}$ of the flaccid leaves were mixed with $650 \mathrm{ml}$ of phosphate buffer $(0.05 \mathrm{M}, \mathrm{pH}$ 6.6) in a blender. The resulting slurry was filtered through cheesecloth, and another 3 liters of buffer and 2 liters of distilled water were poured through the slurry to make a suspension of teliosori with limited amounts of extrane- ous leaf material. A spreader-sticker, NuFilm 17 (Pinolene, Miller Chemical and Fertilizer Corp., Hanover, PA), was added at a rate of $2.4 \mathrm{ml}$ per 3.8 liters of suspension immediately prior to application. The suspension was applied to the plots within $2 \mathrm{~h}$.

In 1993, two dyer's woad-infested sites, Preston Valley and Chokecherry, were chosen for rust inoculation. Both were adjacent to and north of US 89 in Logan Canyon, $14.5 \mathrm{~km}$ east of Logan, at 1,600-m elevation. Less than $1 \%$ of the dyer's woad plants in the indigenous population was rust-infected. Chokecherry was a gentle south-facing slope with mixed vegetation of shrubs, grass and forbs, and bigtooth maple (Acer grandidentatum). Preston Valley was in a narrow canyon with grasses and herbaceous vegetation.

The inoculation experiments were conducted as randomized complete block designs with three treatments and five blocks. Treatments included dry inoculum, the wet inoculum suspension, and an untreated check. Individual plots were $1 \mathrm{~m}^{2}$ plus approximately $15 \mathrm{~cm}$ of border area outside each edge of the plot. A 100-g portion of the dry talc-inoculum mixture was applied to each of five plots, using a pesticide dust applicator. One liter of liquid inoculum was applied to each of the five other plots, using a backpack sprayer with a hollow cone nozzle and no filter. Plants were inoculated at Preston Valley and Chokecherry 3 and 4 June 1993, respectively.

A portion of dry inoculum was retained from both inoculations and stored at $-20^{\circ} \mathrm{C}$ for later quantification of sori. Sori were counted on each leaf piece in each of five 10-mg samples. At Chokecherry and Preston Valley, dry inoculum concentrations were $1.6 \times 10^{4}$ and $1.9 \times 10^{4}$ sori per gram, respectively (resulting in 1.2 and $1.4 \times 10^{6}$ sori per $\mathrm{m}^{2}$, respectively). Sori in the liquid suspension were not quantified. Inoculated sites were evaluated in spring 1994. Asymptomatic and symptomatic plants were counted, and percent plants with symptoms was calculated for each plot. The chisquare test was used to examine the null hypothesis that there were no differences in percent infection due either to inoculum type or block (6).

Basidiospore production. In June 1995, rust-infected dyer's woad plants with sori on the leaves were collected, air-dried, and stripped of leaves. Leaves were ground to approximately 2 to $3 \mathrm{~mm}^{2}$ pieces. Leaf pieces were sealed in an airtight plastic container and stored at $-20^{\circ} \mathrm{C}$ for up to 5 months. Teliospores remain viable at $-20^{\circ} \mathrm{C}$ for over a year (K. M. Flint, unpublished).

The effect of temperature on basidiospore production from teliosori was examined at $0,5,10,15,20$, and $25^{\circ} \mathrm{C}$. A single Freas 815 Low Temperature Incubator (GCA/Precision Scientific, Chicago,
IL) was used for the experiment and reset for each exposure. All six temperatures were run in randomly assigned order, constituting one replication. The series was replicated three times.

For each replication of each temperature exposure, 12 leaf pieces bearing sori were selected from the stored leaf pieces. The pieces were placed briefly on the surface of water agar to moisten and facilitate cutting them. The leaf pieces were then examined under a dissecting microscope, and one fragment bearing three apparently mature sori was cut from each leaf piece. These fragments were placed on the surface of water agar in the bottom of a $150-\mathrm{mm}$ diameter petri dish. This was inverted so that the leaf pieces were suspended above $15-\mathrm{mm}$ water agar disks placed on four sterile microscope slides in the lid of the dish. The petri dish was then placed in a plastic bag and put into the incubator.

At intervals of $3,6,12$, and $24 \mathrm{~h}$, the slides bearing the agar disks were removed from the petri dish and replaced with fresh slides and agar disks. The plate was then returned to the incubator for the next interval. The incubated disks were stained with a drop of lacto-fuchsin stain (5) to stop spore germination and fix the spores, and stored at $5^{\circ} \mathrm{C}$ until examination.

Basidiospores fell onto the agar disks, usually in a tight pattern, and were located using a dissecting microscope. Spore production was evaluated by counting the basidiospores in 10 random fields on each agar disk at $\times 900$ magnification. Spore counts for the 12 agar disks were averaged to give a mean for the exposure period. The number of spores with germ tubes longer than the spore diameter on each agar disk was counted and averaged for the exposure period.

The cumulative number of spores produced over the four exposure periods, i.e., the total for $24 \mathrm{~h}$, was analyzed using oneway analysis of variance and Tukey's paired comparison procedure (21). The square root transformation was applied, but it did not improve the analysis. Therefore, the analysis was done on the original data. To test for interaction between temperature and incubation interval, the number of spores produced per sorus per hour for each interval was calculated; these data were analyzed using the two-way factorial design, split-plot-over-time.

\section{RESULTS}

Timing of field infections. None of the check plants at the LO nursery showed symptoms of infection during the incubation of plants exposed at BC, WC, GC, or NL throughout 1992 and 1993.

1991 Brigham City. Plants were infected during the 26 April, 10 May, and 24 May exposure periods, but not after 7 June (Fig. 2 ). There was no significant difference in percent infection among the three exposure periods when infections occurred. No 
plants were exposed at Brigham City between 19 July and 16 August, as inoculum source plants were dead or dormant and therefore were not producing inoculum. Symptoms on some infected plants became apparent in the autumn when plants were 18 to 24 weeks old. The remainder of the plants showed symptoms the following spring, 44 to 51 weeks after the beginning of the exposure period.
1991 Wellsville Canyon. Plants were infected during six consecutive exposure periods beginning on 10 May (Fig. 2). There was a significant difference $(P=$ $0.003)$ in percent infection among those exposure periods, with the most infections occurring during the 2-week periods following 24 May and 4 July. No infections occurred between 12 April and 10 May, between 2 August and 16 August, or be-

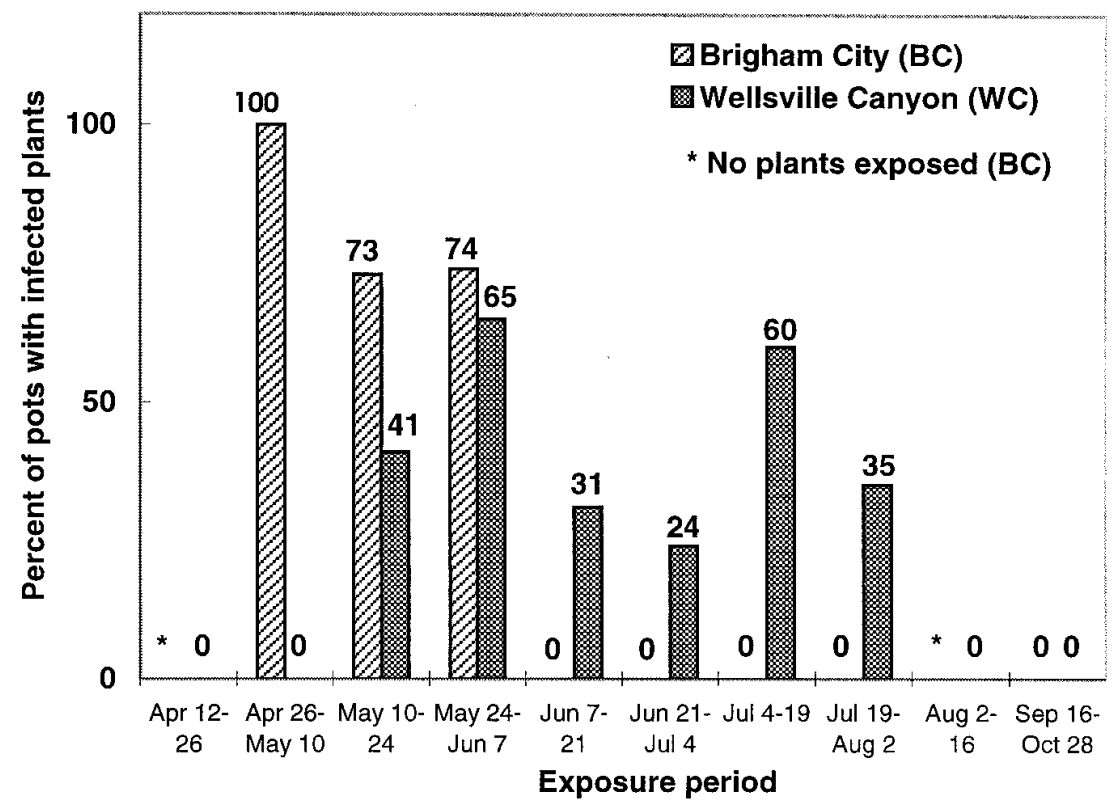

Fig. 2. Incidence of infection of dyer's woad by rust at Wellsville Canyon (WC) and Brigham City (BC) during 2-week exposure periods in 1991. The final exposure period lasted 6 weeks. Asterisks (*) indicate that no plants were exposed in the given period at BC. Data for all plant age groups are pooled for each exposure period.

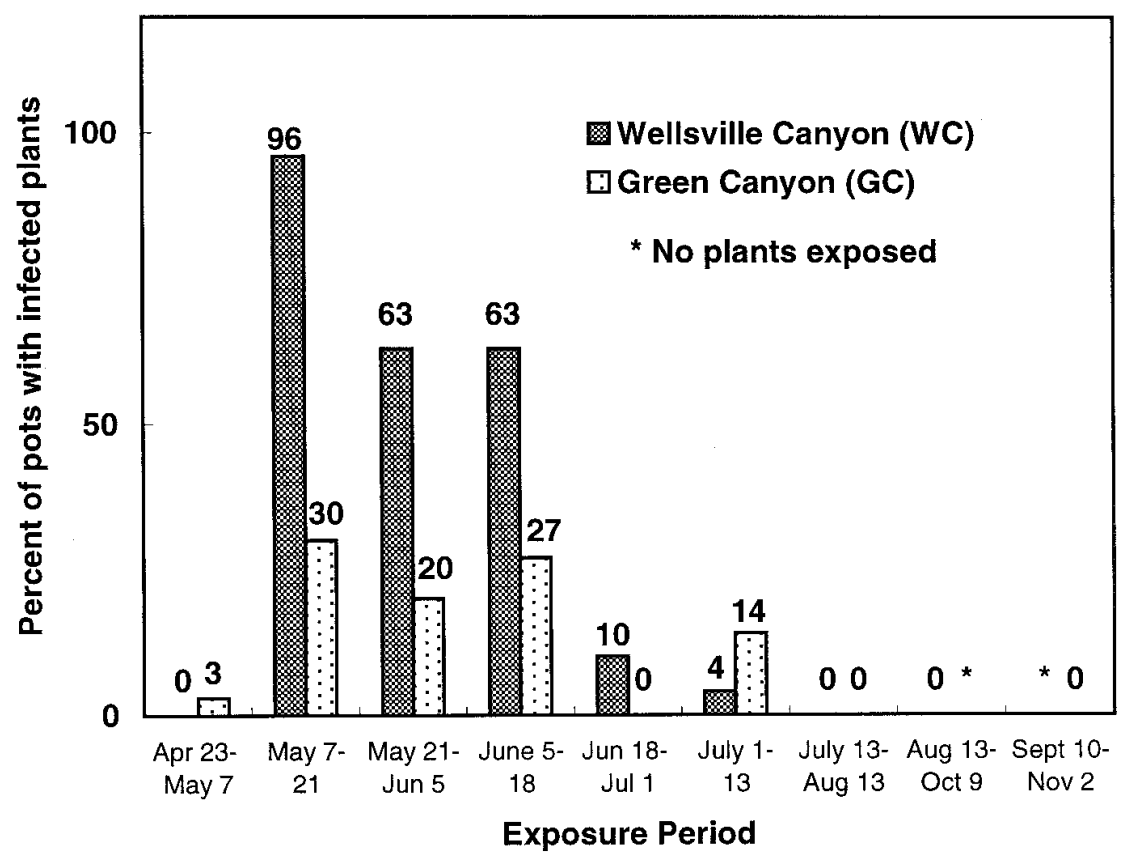

Fig. 3. Incidence of infection of dyer's woad by rust at Wellsville Canyon (WC) and Green Canyon (GC) during 2-week exposure periods in 1992. Asterisks $(*)$ indicate that no plants were exposed in a particular period. Data for various plant age groups are pooled for each exposure period. Several exposure periods beginning with 13 July are represented together to simplify the graph.

tween 16 September and 28 October. No plants were exposed between 16 August and 16 September, because the inoculum source plants were dead or dormant. Symptoms became apparent on some plants as early as 12 to 22 weeks and up to 36 to 47 weeks after the beginning of any particular exposure period.

1992 Wellsville Canyon. Plants were infected in all of the 2-week periods from 7 May through 13 July (Fig. 3). Although plants were exposed continuously thereafter through 9 October, additional infections did not occur. Infections did not occur in the 2 weeks prior to 7 May. The response of infection to exposure date was significant $(P<0.0001)$, with the highest incidence of infection $(96 \%)$ occurring the 2 weeks following 7 May. Between 9 and 25 weeks elapsed between time of exposure and symptom expression in the exposed plants. All infected plants expressed symptoms in the fall of 1992, and plants that were asymptomatic in the fall remained asymptomatic.

1992 Green Canyon. The highest incidence of infection (30\%) occurred in the 2 weeks beginning 7 May (Fig. 3). Plants were infected during the four consecutive 2-week exposure periods between 23 April and 18 June, and also in the period from 1 to 13 July. Plants exposed from 18 June through 1 July or between 13 July and 13 August were not infected. The response due to exposure period was significant $(P=$ 0.005). The earliest appearance of symptoms on plants exposed to rust occurred in the fall, 9 to 25 weeks after exposure; the latest occurred the following spring, 44 to 54 weeks after exposure.

There was no apparent relation, in any of the experiments, between either exposure period or age of plants at exposure time and the number of days or weeks until symptoms were expressed (i.e., the length of the latent period).

Plant age. There was no significant difference due to the age of the plants at BC or GC in either 1991 or 1992 , or at WC in 1992. For WC in 1991, the chi-square test indicated a significant effect of plant age on infection $(P=0.015)$, with younger plants more susceptible. There was no apparent effect of interaction between exposure period and age on the outcome of the exposure, at any of the sites in either year.

Fall infections. The only fall infections occurred in 8 of the $35(23 \%)$ pots of plants exposed at NL in 1992.

Inoculation of natural stands. Chokecherry 1993 to 1994 . Inoculations with fresh and dry inoculum resulted in 62 and $66 \%$ of the plants infected, respectively, compared with $2 \%$ infection in the check plots. The inoculated treatments were significantly different from the check $(P<$ $0.0001)$ but not from each other. There was also a significant $(P<0.0001)$ difference due to blocks. 
Preston Valley 1993 to 1994. The dry inoculum plots had $76 \%$ infection compared with $58 \%$ in plots inoculated with fresh inoculum and $7 \%$ in the check plots. Inoculum treatments were significantly different from each other and from the check $(P<0.0001)$, as were blocks $(P=$ 0.030).

Basidiospore production. Basidiospores were readily produced when sori were placed on the surface of water agar and suspended over water agar disks. They were found in a tightly clustered group on the surface of the agar disk. The mean numbers of basidiospores produced at 0,5 , $10,15,20$, and $25^{\circ} \mathrm{C}$ within a 24 -h period were $0,45,163,248,129$, and 0 , respectively (Fig. 4). Tukey's least significant difference between means at $24 \mathrm{~h}$ was 56 $(P<0.05)$. The rate of spore production over time varied significantly, depending on incubation temperature, with the highest rate usually at $15^{\circ} \mathrm{C}$ (Fig. 5). At 10, 15, and $20^{\circ} \mathrm{C}$, more spores were produced per hour between 3 and $6 \mathrm{~h}$; but at $5^{\circ} \mathrm{C}$, no spores were produced until after $6 \mathrm{~h}$ of incubation. A few spores were detected immediately after the first $3 \mathrm{~h}$ of incubation at 15 and $20^{\circ} \mathrm{C}$.

Basidiospores germinated at temperatures ranging from 5 to $20^{\circ} \mathrm{C}$ (Table 1). Germination took more than $3 \mathrm{~h}$ at all temperatures. No basidiospores were produced at 0 and $25^{\circ} \mathrm{C}$, so no germination data are available.

\section{DISCUSSION}

Rust infection of dyer's woad occurs over several weeks, principally in the springtime, when cool temperatures prevail and rain is frequent. Infected plants were also common through June or July, depending on the year and the site; but infection was rare from early August through October at any of the sites.

It is clear from our studies with basidiospore production and germination that temperatures above $20^{\circ} \mathrm{C}$ and less than $5^{\circ} \mathrm{C}$ greatly reduce the availability of inoculum. Plants may have been infected earlier in April at GC and BC, since the first plants we exposed, on 23 and 26 April, respectively, became infected. However, we did define the infection periods at WC in both 1991 and 1992. The infection period lasted longer into the summer at WC, compared with BC and GC, presumably because WC is at a higher elevation, with consequent lower temperatures and perhaps more frequent rain later in the summer. This climatic difference due to elevation also seems to prolong the period of inoculum availability, because plants producing inoculum remained succulent later in the season than those at lower elevations.

Occasionally, teliosori appear in autumn on indigenous plants, suggesting that plants may be infected in the fall in natural situations. We observed fall infection at NL in 1992, but the incidence of infection was low compared with that achieved in some of the spring exposure periods.

Plants were infected at WC when rainfall ranged from 1 to $5 \mathrm{~cm}$ per 2-week exposure period with daily mean temperatures between 13 and $20^{\circ} \mathrm{C}$. However, when similar weather conditions prevailed at $\mathrm{WC}$ during later exposure periods, there were no infections. A similar situation occurred at GC. Both the indigenous infected plants at WC and the potted inoculum-producing plants at GC had abundant cinereous sori during the exposure periods when most of the infections occurred. As the season progressed, sori gradually degenerated, and no cinereous sori were found during the periods when infection did not occur. Therefore, it is presumed that lack of inoculum, not unfavorable weather conditions, prevented infection later in the season.

In three of the four studies of the timing of natural infection, the age of rosettes at the time of exposure did not significantly affect the incidence of infection. There was evidence at WC in 1991 that younger ro-

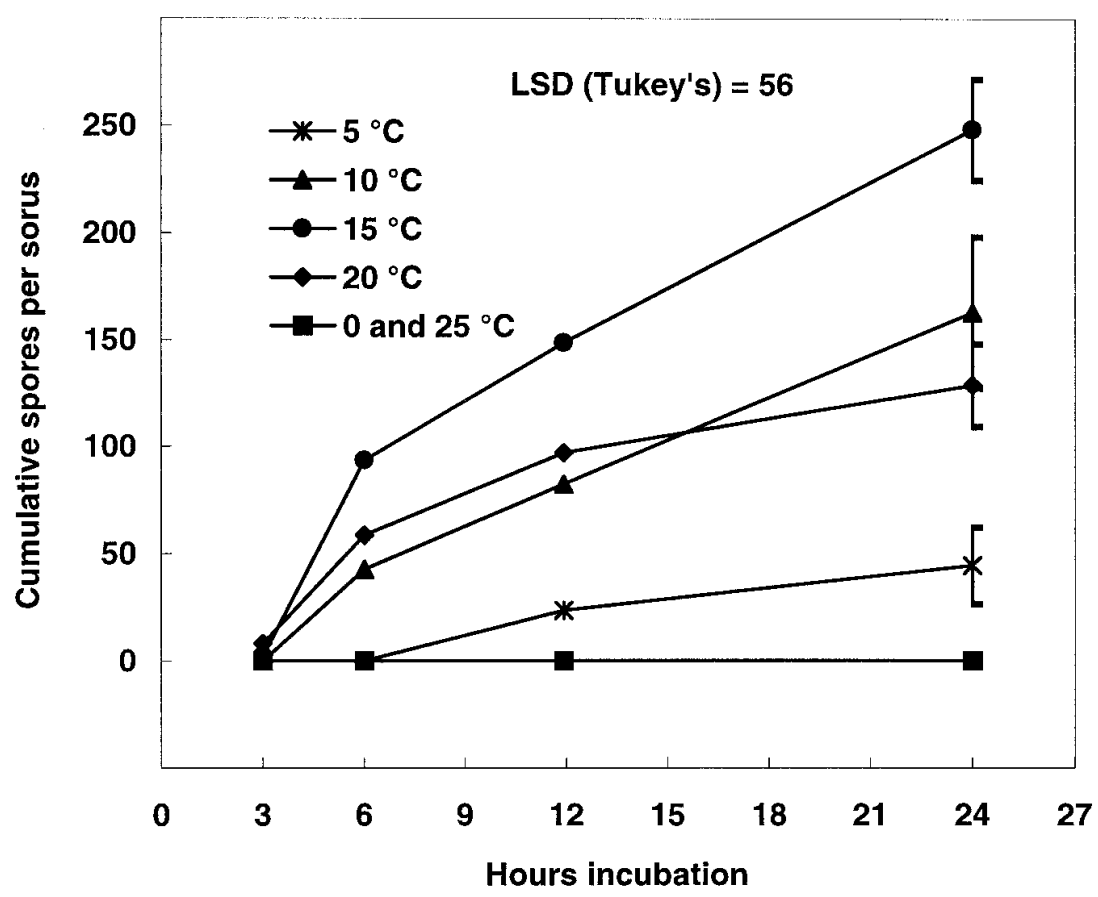

Fig. 4. Effect of temperature on basidiospore production from teliosori in vitro. Data are the means of three repetitions for each temperature. Data are cumulative for the given number of hours. Error bars indicate Tukey's $\operatorname{LSD}_{0.05}$.

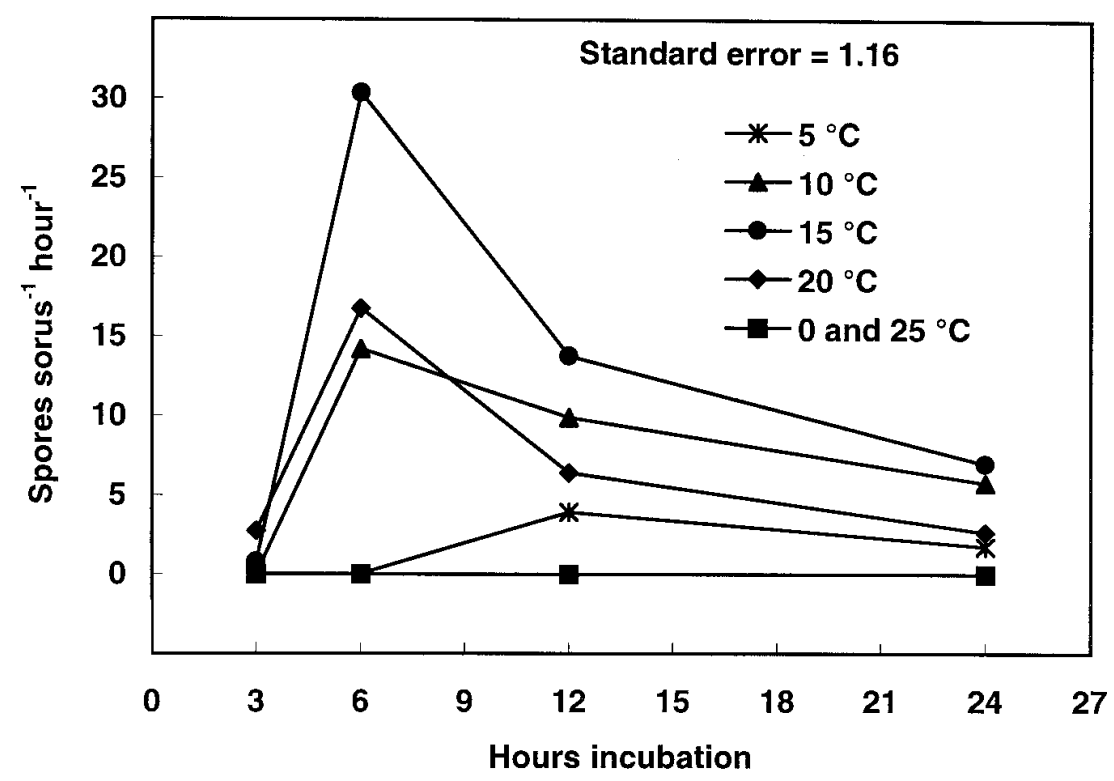

Fig. 5. Effect of temperature on rate of basidiospore production from teliosori in vitro. Data are the means of three repetitions for each temperature. Data are not cumulative over time. 
settes were more susceptible to infection; but this statistical inference was most likely an artifact of an unbalanced statistical design.

Plants infected with rust in the spring and early summer were asymptomatic until at least 9 weeks later and usually up to 45 weeks after inoculation. About $25 \%$ of the plants infected in spring 1991 expressed symptoms in autumn of the same year, and the remainder of the plants remained asymptomatic until the following spring. In contrast, all plants infected in spring 1992 expressed symptoms before they overwintered. In most cases, infected plants became chlorotic and developed spermagonia and telia while still in the rosette stage, before they began to bolt.

The stimuli that trigger symptom expression are unknown. In the field studies, length of the latent period was independent of date of exposure and age of plants at exposure. We know that during the latent period, the fungus grows from the point of initial infection to spread throughout virtually every part of the plant, including the roots (14). Symptoms usually appear first in young leaves in the center of rosettes, before bolting. However, symptoms may appear first in older parts of the plant, or shoots may become infected and never show symptoms.

The extended latent period in the life cyat inoculation were considered unsuccessful (16). It was expected that plants inoculated with teliospores-basidiospores would exhibit rust symptoms soon thereafter. When no symptoms developed after a few months in the greenhouse, the plants were discarded. Had the plants been kept for up to a year, and perhaps given a cold treatment, it is likely that symptoms would have appeared. Young seedlings inoculated in a dew chamber and transferred to the greenhouse express symptoms within 10 to 13 weeks (14).

We achieved a high incidence of infection (in excess of $60 \%$ ) in inoculated plots at two sites in 1993. Our results contrasted with those of Lovic (16), who reported lower and less consistent incidence of inple intact sori, whereas Lovic scraped germinated teliospores from cinereous sori and suspended them in water, applying this cle of this rust suggests why early attempts fection. We used leaf pieces bearing multi-

suspension to rosettes. Previous studies with different rusts have shown that teliospores germinate poorly when removed from the sori (18). French and Lightfield (10) germinated detached teliospores only with germination stimulants. In numerous attempts, we have not been able to germinate teliospores when they were detached from the sori (K. M. Flint, unpublished).

The optimum temperature for basidiospore production is $15^{\circ} \mathrm{C}$, with no basidiospores produced at 0 or $25^{\circ} \mathrm{C}$. It was surprising to learn that basidiospores were produced at $5^{\circ} \mathrm{C}$, since basidiospore production in other rusts did not occur at $5^{\circ} \mathrm{C}$ $(10,18)$. It is clear that this rust is well adapted to cold temperatures common in the spring.

When teliospores were incubated at optimum conditions ( 15 and $20^{\circ} \mathrm{C}$ ), basidiospores were produced after just $3 \mathrm{~h}$. Morin et al. (18) obtained similar results with Puccinia xanthii. The sori chosen for placement on water agar in our tests were occasionally cinereous; so it cannot be ruled out that at least some basidiospores were present before the incubation period. However, the lack of basidiospores at 0 and $25^{\circ} \mathrm{C}$ supports our suggestion that the spores were produced in situ rather than being present on teliosori before being placed on the water agar.

Woad rust is an excellent prospect for biological control of dyer's woad. These studies establish that the rust is capable of producing spores quickly under cool temperatures to take advantage of the frequent, intermittent spring showers that occur in the Intermountain West. We have also demonstrated that the rust produces basidiospores over a wide range of temperatures. Woad rust is systemic, so conceivably a single basidiospore could infect the entire plant. It is not necessary to obtain multiple infections, which would be required for local lesion pathogens. Infected plants rarely produce seeds, and consequently reproduction is greatly reduced. The rust is probably native to North America (15), and this precludes the necessity of searching for or releasing an exotic pathogen. The rust is capable of spreading on its own, but we have shown that the incidence of infection can be increased with properly timed inoculations. Finally, the woad rust seems to be host-specific and

Table 1. Effect of temperature on the percent germination of basidiospores on agar $^{\mathrm{a}}$

\begin{tabular}{lcccccc}
\hline & \multicolumn{7}{c}{ Incubation temperature, ${ }^{\circ} \mathbf{C}^{\mathbf{b}}$} \\
\cline { 2 - 7 } Hours incubation & $\mathbf{0}$ & $\mathbf{5}$ & $\mathbf{1 0}$ & $\mathbf{1 5}$ & $\mathbf{2 0}$ & $\mathbf{2 5}$ \\
\hline 0 to 3 & - & 0 & 0 & 0 & 0 & - \\
3 to 6 & - & 0 & 0.3 & 12 & 23 & - \\
6 to 12 & - & 31 & 19 & 26 & 36 & - \\
12 to 24 & - & 50 & 33 & 75 & 82 & - \\
\hline
\end{tabular}

${ }^{a}$ Values given are percent germination of basidiospores produced in the given incubation interval. Basidiospores examined in one interval are different spores from those examined in any other interval. Therefore, germination values are not cumulative over $24 \mathrm{~h}$.

${ }^{\mathrm{b}}$ No spores were produced at 0 and $25^{\circ} \mathrm{C}$. apparently does not cause disease in other plant species (15).

\section{ACKNOWLEDGMENTS}

Research was supported in part by the Utah Department of Agriculture and Food. We thank Helen Darrow for patient and reliable technical assistance.

\section{LITERATURE CITED}

1. Arthur, J. C. 1934. Manual of the Rusts in the United States and Canada. Purdue Research Foundation, Lafayette, IN.

2. Asghari, J. B., Evans, J. O., and Dewey, S. A. 1992. Low temperature vernalization forces dyer's woad (Isatis tinctoria L.) flowering. Res. Prog. Rep. West. Soc. Weed Sci. 1992:VI/6-7.

3. Callihan, R. H. 1990. Dyers woad: Biology, distribution, and control. Univ. Idaho Coop. Ext. Serv. CIS 857.

4. Callihan, R. H., Dewey, S. A., Patton, J. E., and Thill, D. C. 1984. Distribution, biology, and habitat of dyer's woad (Isatis tinctoria) in Idaho. J. Idaho Acad. Sci. 20:18-32.

5. Carmichael, J. W. 1955. Lacto-fuchsin: A new medium for mounting fungi. Mycologia 47:611.

6. Cochran, W. G., and Cox, G. 1957. Experimental Design. Ed. 2. John Wiley \& Sons, New York. pp.103-105.

7. Dewey, S. A., Price, K. P., and Ramsey, D. 1991. Satellite remote sensing to predict potential distribution of dyer's woad (Isatis tinctoria). Weed Technol. 5:479-484.

8. Evans, J. O. 1991. The importance, distribution, and control of dyer's woad (Isatis tinctoria). Pages 387-393 in: Noxious Range Weeds, Lynn F. James, L. F. James, J. D. Evans, M. H. Ralphs, and R. D. Child, eds. Westview Press, Boulder, CO.

9. Farah, K. O., Tanaka, A. F., and West, N. E. 1988. Autecology and population biology of dyer's woad (Isatis tinctoria). Weed Sci. 36:186-193.

10. French, R. C., and Lightfield, A. R. 1990. Induction of systemic aecial infection in Canada thistle (Cirsium arvense) by teliospores of Puccinia punctiformis. Phytopathology 80:872-877.

11. Hiratsuka, Y., and Hiratsuka, N. 1980. Morphology of spermagonia and taxonomy of rust fungi. Rep. Tottori Mycol. Inst. 18:257-268.

12. Intermountain Region Noxious Weed and Poisonous Plant Control Program Environmental Impact Statement. 1986. U.S. Dep. Agric. For. Serv., Intermountain Region, Ogden, UT.

13. King, L. J. 1967. The distribution of woad (Isatis tinctoria L., Cruciferae) in North America. Proc. N.E. Weed Control Conf. 21:589-593.

14. Kropp, B. R., Hansen, D., Flint, K. M., and Thomson, S. V. 1996. Artificial inoculation and colonization of dyer's woad (Isatis tinctoria) by the systemic rust fungus Puccinia thlaspeos. Phytopathology 86:891-896.

15. Kropp, B. R., Hansen, D. R., Wolf, P. G., Flint, K. M., and Thomson, S. V. 1997. A study on the phylogeny of the dyer's woad rust fungus and other species of Puccinia from Crucifers. Phytopathology 87:565571.

16. Lovic, B. R. 1991. Two potential biocontrol strategies: Puccinia thlaspeos Schub. for Isatis tinctoria L. (Dyer's Woad), and sugar beet associated bacteria for Phoma betae. M.S. thesis. Utah State University, Logan.

17. McConnell, E. G., Dewey, S. A., Thomson, S. V., and Schupp, E. W. 1997. Effect of a native rust on population dynamics of dyer's woad. Proc. Western Soc. Weed Sci. 50:44-45.

18. Morin, L., Brown, J. F., and Auld, B. A. 1992. 
Effects of environmental factors on teliospore germination, basidiospore formation, and infection of Xanthium occidentale by Puccinia xanthii. Phytopathology 82:1443-1447.

19. Northwest Area Noxious Weed Control Program Environmental Impact Statement. 1985. USDI, Bureau of Land Management, Port- land, OR.

20. Shaw, R. J. 1989. Vascular Plants of Northern Utah: An Identification Manual. Utah State University, Logan.

21. Tukey, J. W. 1949. Comparing individual means in the analysis of variance. Biometrics 5:99-114.
22. Varga, W. A., and Evans, J. O. 1978. Dyer's woad: From cultivated to cursed. Utah Sci. 39:87-89.

23. Young, J. A., and Evans, R. A. 1971. Germi nation of dyer's woad. Weed Sci. 19:76-78.

24. Young, J A., and Evans, R. A. 1977. Today's weed: Dyer's woad. Weeds Today 9:1. 